\title{
Chaperones in Neurodegeneration
}

\author{
Iris Lindberg, ${ }^{1}$ James Shorter, ${ }^{2}$ R. Luke Wiseman, ${ }^{3}$ Fabrizio Chiti, ${ }^{4}$ Chad A. Dickey, ${ }^{5}$ and $\odot$ Pamela J. McLean ${ }^{6}$ \\ ${ }^{1}$ University of Maryland School of Medicine, Baltimore, Maryland 21201, ${ }^{2}$ University of Pennsylvania, Philadelphia, Pennsylvania 19104, ${ }^{3}$ The Scripps \\ Research Institute, La Jolla, California 92037, ${ }^{4}$ University of Florence, 50121 Florence, Italy, ${ }^{5}$ University of South Florida, Tampa, Florida 33620 , and ${ }^{6}$ Mayo \\ Clinic, Jacksonville, Florida 32224
}

Cellular protein homeostasis (proteostasis) maintains the integrity of the proteome and includes protein synthesis, folding, oligomerization, and turnover; chaperone proteins assist with all of these processes. Neurons appear to be especially susceptible to failures in proteostasis, and this is now increasingly recognized as a major origin of neurodegenerative disease. This review, based on a minisymposium presented at the 2015 Society for Neuroscience meeting, describes new work in the area of neuronal proteostasis, with a specific focus on the roles and therapeutic uses of protein chaperones. We first present a brief review of protein misfolding and aggregation in neurodegenerative disease. We then discuss different aspects of chaperone control of neuronal proteostasis on topics ranging from chaperone engineering, to chaperone-mediated blockade of protein oligomerization and cytotoxicity, to the potential rescue of neurodegenerative processes using modified chaperone proteins.

Key words: chaperone; heat shock proteins; protein misfolding; proteostasis; neurodegeneration; Parkinson's disease

\section{Significance Statement}

Aberrant protein homeostasis within neurons results in protein misfolding and aggregation. In this review, we discuss specific roles for protein chaperones in the oligomerization, assembly, and disaggregation of proteins known to be abnormally folded in neurodegenerative disease. Collectively, our goal is to identify therapeutic mechanisms to reduce the cellular toxicity of abnormal aggregates.

\section{Introduction}

Proteostasis is a collection of cellular processes, including protein synthesis, folding, oligomerization, and turnover, that functions to ensure the integrity of the proteome. For unknown reasons, neurons appear to be particularly susceptible to genetic and environmental insults to proteostasis, and aberrant proteostasis is now acknowledged as a major underlying cause of neurodegenerative disease (for review, see Doyle et al., 2013; Hetz and Mollereau, 2014; Valastyan and Lindquist, 2014). Protein misfolding and aggregation can induce specific neurotoxic events that underlie a number of lethal and presently untreatable neurodegenerative diseases. Aggregation-susceptible proteins in-

Received July 8, 2015; revised Aug. 31, 2015; accepted Sept. 1, 2015. Author contributions: I.L., J.S., R.L.W., F.C., C.A.D., and P.J.M. wrote the paper

This work was supported by National Institutes of Health Grants AG045741 and DA05084 to I.L., National Institutes of Health Grants GM099836, DP20D002177, and NS067354, as well as Muscular Dystrophy Association MDA277268, and Target ALS to J.S., National Institutes of Health Grants NS092829 and DK102635 and the Amyloidosis Foundation to R.L.W., National Institutes of Health Grants MH103848 and NS073899 to C.A.D., and National Institutes of Health Grant NS073740 to P.J.M.

The authors declare no competing financial interests.

Correspondence should be addressed to Dr. Iris Lindberg, Department of Anatomy and Neurobiology, University of Maryland Medical School, 20 Penn Street, HSF2, S251, Baltimore, MD 21210. E-mail: ilindberg@som.umaryland.edu.

DOI:10.1523/JNEUROSCI.2600-15.2015

Copyright $\odot 2015$ the authors $\quad 0270-6474 / 15 / 3513853-07 \$ 15.00 / 0$ clude, but are not limited to, tau and $\beta$-amyloid in Alzheimer's disease; $\alpha$-synuclein ( $\alpha$-syn) in Parkinson's disease; RNAbinding proteins with prion-like domains in frontotemporal dementia and amyotrophic lateral sclerosis; polyglutaminecontaining proteins in Huntington's disease and spinal cerebellar ataxias; and prion proteins in Creuzfeldt-Jakob disease. There have been recent relevant reviews (Eisenberg and Jucker, 2012; Ling et al., 2013; Knowles et al., 2014).

Misfolded and aggregated proteins present a significant cellular burden that must be dealt with. Protein chaperones can prevent the aggregation of unfolded polypeptide chains (Hartl et al., 2011; Kim et al., 2013), promote their de novo folding or refolding (Hartl et al., 2011; Kim et al., 2013), cooperate with proteases to facilitate protein degradation (Pickart and Cohen, 2004; Alexopoulos et al., 2012; Li and Lucius, 2013), and disaggregate protein aggregates (Weibezahn et al., 2005; Hodson et al., 2012; Winkler et al., 2012). Increasing evidence implicates chaperone proteins in the etiology of neurodegenerative disease involving aggregative processes. Neuroprotection studies show that many different chaperone proteins are neuroprotective in various mouse models of neurodegeneration (for recent reviews, see Wyatt et al., 2012; Carman et al., 2013; Witt, 2013).

In the following summary of our mini-symposium, different aspects of chaperone action in neurodegenerative processes are 
discussed, from the regulation of extracellular proteostasis to the design of therapeutic molecules.

\section{Protein disaggregases to counter neurodegeneration}

There are still no effective therapeutics that directly target and remediate the protein-misfolding events and selective neuronal vulnerability that underpin the many devastating neurodegenerative disorders. Therapeutic agents that reverse deleterious protein misfolding and aggregation in a manner that restores previously misfolded proteins to native form and function could be highly beneficial as they would simultaneously eliminate any deleterious loss of function or toxic gain of function caused by misfolded conformers (Jackrel and Shorter, 2015). Moreover, this type of disruptive technology would also eradicate any aberrant self-templating or prion-like conformers that spread disease pathology and drive the biogenesis of toxic, soluble oligomers (Knowles et al., 2014; Jackrel and Shorter, 2015).

Efficacious therapeutic agents have been constructed by protein engineering of the heat shock protein Hsp104, a protein disaggregase and ATPase associated with diverse activities $\left(\mathrm{AAA}^{+}\right.$) protein from yeast (Jackrel and Shorter, 2015). In yeast, Hsp104 collaborates with the other heat shock proteins Hsp110, Hsp70, Hsp40, and small heat shock proteins to effectively disaggregate and reactivate proteins trapped in disordered aggregates after environmental stresses, such as heat shock (Glover and Lindquist, 1998; Cashikar et al., 2005; Shorter, 2011; Torrente and Shorter, 2013). Moreover, Hsp104 can also dissolve diverse amyloid conformers and eliminate toxic, soluble preamyloid oligomers (Shorter and Lindquist, 2004; Lo Bianco et al., 2008; DeSantis et al., 2012). However, Hsp104 activity against human neurodegenerative disease proteins is often limited and requires very high levels of Hsp104 (DeSantis et al., 2012). Thus, the Hsp104 sequence must be modified to effectively disaggregate misfolded proteins tightly linked with Parkinson's disease, amyotrophic lateral sclerosis, and frontotemporal dementia (Jackrel and Shorter, 2015).

Remarkably, very subtle modifications of the Hsp104 primary sequence (e.g., a single Ala to Gly or Val to Leu substitution) can yield large gains in protective activity against deleterious misfolding of $\alpha$-syn, the aggregated protein in Parkinson's disease (Jackrel and Shorter, 2014; Jackrel et al., 2014). These potentiated Hsp104 variants also reverse the misfolding and toxicity of proteins connected with ALS and FTD, including several RNAbinding proteins with prion-like domains: TDP-43, FUS, and TAF15 (Jackrel and Shorter, 2014; Jackrel et al., 2014). Unusually, in many cases, loss of amino acid identity at select positions in the autoinhibitory coiled-coil middle domain of Hsp 104, rather than specific mutation, empowers a dramatic therapeutic gain of function (Jackrel and Shorter, 2014; Jackrel et al., 2014). Typically, potentiating mutations in Hsp104 enhance ATPase activity, reduce dependence on the Hsp70 chaperone system, and enhance protein translocase and remodeling activity (Jackrel and Shorter, 2014; Jackrel et al., 2014). Importantly, potentiated Hsp104 variants also provide neuroprotection in the context of the metazoan nervous system and prevent dopaminergic neurodegeneration caused by $\alpha$-syn in Caenorhabditis elegans (Jackrel et al., 2014).

Potentiated Hsp104 variants may also be used against other proteins that misfold in neurodegenerative disease, including the $\beta$-amyloid polypeptide-derived peptide $\mathrm{A} \beta$, tau, and SOD1 (Cushman et al., 2010). However, some human neurodegenerative disease proteins are more refractory to potentiated Hsp104 variants. For example, the misfolding and toxicity of EWSR1, an RNA-binding protein with a prion-like domain linked to amyotrophic lateral sclerosis and frontotemporal dementia (Couthouis et al., 2012; King et al., 2012), could not be buffered by potentiated Hsp104 variants (Jackrel and Shorter, 2014). This finding suggests that further amelioration of Hsp104 disaggregase activity or alteration of substrate specificity may be necessary. Laboratory evolution of alternative potentiated Hsp104 variants can potentially generate selectivity for individual human disease substrates to maximize therapeutic efficacy and minimize any potential toxic, off-target effects. Collectively, these studies suggest that general neuroprotection could be achievable for several diverse neurodegenerative conditions via remarkably subtle structural modifications of existing molecular chaperones or protein disaggregases (Jackrel and Shorter, 2015).

\section{Regulation of extracellular proteostasis through the unfolded protein response}

Extracellular protein aggregation is also intricately associated with the onset and pathogenesis of etiologically diverse amyloid diseases, including the systemic amyloidoses and neurodegenerative disorders, such as Alzheimer's disease and Creutzfeldt-Jakob disease (Blancas-Mejía and Ramirez-Alvarado, 2013; Knowles et al., 2014). In these disorders, specific misfolding-prone proteins fail to maintain a folded conformation in the extracellular space, which facilitates their aggregation into proteotoxic soluble oligomers and amyloid fibrils. All of the proteins associated with amyloid disease pathology are targeted to the endoplasmic reticulum (ER) where they interact with ER protein homeostasis (or proteostasis) factors, such as chaperones to attain a folded conformation. Once folded, these proteins are trafficked to the extracellular space through the canonical secretory pathway. Imbalances in ER proteostasis induced by ER stress can increase the secretion of misfolded conformations of amyloidogenic proteins and promote the extracellular proteotoxic aggregation involved in amyloid disease pathology. As such, ER stress is associated with the onset and pathology of many human amyloid diseases (Ryno et al., 2013; Hetz and Mollereau, 2014).

The predominant stress-responsive signaling pathway responsible for regulating ER proteostasis is the unfolded protein response (UPR) (Walter and Ron, 2011). The UPR is activated in response to pathologic insults that induce ER stress. Activation of the UPR restores ER proteostasis primarily through the transcriptional remodeling of ER protein folding, trafficking, and degradation pathways. Activation of UPR signaling pathways enhances ER quality control and attenuates secretion and subsequent extracellular proteotoxic aggregation of destabilized, misfolding-prone proteins associated with amyloid disease pathology (Shoulders et al., 2013; Cooley et al., 2014; Genereux et al., 2015). Despite the importance of UPR signaling in preventing the secretion of destabilized, amyloidogenic proteins, the involvement of the UPR in regulating extracellular proteostasis pathways, composed of ATP-independent secreted chaperones (e.g., clusterin) (Wyatt et al., 2013), is poorly understood. Furthermore, the specific mechanisms by which UPR signaling coordinates ER and extracellular proteostasis pathway composition and activity are largely unknown. Because ER stress has the potential to influence the secretion and subsequent proteotoxic aggregation of amyloidogenic proteins, it is important to evaluate how UPR activation regulates extracellular proteostasis following pathologic ER insults.

A bioinformatics approach was used to identify ERdj3/ DNAJB11 as a UPR-regulated secreted chaperone that promotes extracellular proteostasis during conditions of ER stress (Genereux et al., 2015). ER stress and stress-independent activation 
of UPR-associated transcription factors induce ERdj3 secretion to the extracellular space. Secreted ERdj3 binds to misfolded proteins and attenuates proteotoxic misfolding and/or aggregation of amyloidogenic proteins, including the $A \beta$ peptide and toxic prion protein conformations involved in Alzheimer's disease and Creutzfeldt-Jakob disease, respectively. Moreover, ERdj3 is cosecreted with destabilized, amyloidogenic proteins during conditions when ER proteostasis pathways are overwhelmed, preemptively protecting the extracellular environment from misfolding-prone proteins that can be secreted during conditions of ER stress. Ultimately, these results identify UPR-dependent increases in ERdj3 secretion as a previously unanticipated mechanism by which the UPR directly regulates extracellular proteostasis capacity during conditions of ER stress. Furthermore, ERdj3 cosecretion with misfolded protein conformations provides a mechanism to coordinate intracellular and extracellular proteostasis environments in response to pathologic insult. The identification of ERdj3 as a UPR-regulated extracellular chaperone provides a new framework to define the specific contributions of ER stress and UPR signaling in the pathophysiology of amyloid diseases and reveals ERdj3 secretion as a new potential therapeutic target to intervene in these disorders.

\section{Chaperones can bind to and suppress the toxicity of preformed protein oligomers}

As discussed above, protein chaperones act to promote folding, block aggregation, disaggregate proteins, and facilitate protein degradation. In addition to these well-established functions, molecular chaperones have also recently been found to suppress the cytotoxic effects of protein aggregates after these are formed (Ojha et al., 2011; Binger et al., 2013; Cascella et al., 2013; Mannini et al., 2014).

Early studies showed that in vitro incubation of preformed oligomers of the $\mathrm{A} \beta$ peptide with a fivefold lower concentration of Hsp27 (also known as HSPB1) inhibited the oligomer-induced loss of cell viability (Ojha et al., 2011). Biochemical and biophysical methods based on atomic force microscopy, transmission electron microscopy, confocal microscopy coupled to immunostaining, light scattering, and centrifugation assays, in conjunction with SDS-PAGE, showed that Hsp27 inhibited A $\beta$ oligomer toxicity by binding to oligomeric species and converting them into larger aggregates. Interestingly, thioflavin $\mathrm{T}$ fluorescence, 8-anilinonaphthalene-1-sulfonic acid fluorescence, and far-UV circular dichroism spectroscopy provided no evidence for any significant structural change in the preformed oligomers following incubation with Hsp27, indicating that the $A \beta$ structural modification by chaperone involved only quaternary, not secondary or tertiary, structure.

Other chaperones can also suppress the toxicity of misfolded proteins. When preformed misfolded oligomers of $A \beta$, islet amyloid polypeptide, or the model prokaryotic protein HypF-N were incubated in vitro with substoichiometric concentrations of the chaperones $\alpha$ B-crystallin (HSPB5), Hsp70 (HSPA1A), clusterin, $\alpha 2$-macroglobulin, or haptoglobin, they were converted into large nontoxic aggregates, as determined using SDS-PAGE, fluorescence, confocal microscopy coupled to immunofluorescence, and atomic force microscopy (Mannini et al., 2014). Again, conversion of the small oligomers into large aggregates occurred in the absence of any significant structural reorganization of the individual molecules within the aggregates, as determined with Fourier-transform infrared spectroscopy and pyrene labeling. Thus, chaperones can promote further assembly of potentially toxic oligomeric species into larger species.
In addition to the chaperones cited above, human tetrameric transthyretin (hTTR) and its engineered monomeric variant (M-TTR) have also been used to suppress the aggregation of aberrant protein oligomers (Li et al., 2011; Cascella et al., 2013; Li et al., 2013). Although the serum protein hTTR is not generally classified as a chaperone, it had previously been found to prevent the aggregation of $\mathrm{A} \beta$, acting in a chaperone-like manner (Schwarzman et al., 1994; Choi et al., 2007; Buxbaum et al., 2008). Both TTRs, particularly M-TTR, effectively inhibited the toxicity of $\mathrm{A} \beta$ and HypF-N oligomers in vitro. When acting on preformed HypF-N oligomers, the mechanism of action for their biological neutralization was again found to consist of a TTRinduced clustering of the oligomers to produce larger species (Cascella et al., 2013).

Non-neuronal misfolded proteins can also represent substrates for chaperone-mediated structural reorganization. For example, the amyloid fibrils formed by apolipoprotein C-II were converted into large fibrillar tangles in the presence of $\alpha \mathrm{B}$ crystallin (Binger et al., 2013). Although the ability of the individual and assembled fibrils to cause cell dysfunction was not directly tested in this case, the clustered fibrils lost their ability to dissociate into small oligomers and promote secondary nucleation, providing indirect evidence of their diminished toxicity (Binger et al., 2013).

In sum, the ability of protein chaperones to biologically neutralize preformed toxic aggregates is a relatively novel and previously unappreciated function, and is worth further exploration in vitro, in cultured cells and animal models, and in aging and pathological states.

\section{The neuronal secretory chaperones 7B2 and proSAAS suppress the aggregation of neurodegenerative disease-related proteins}

While all cells express the heat shock and common secretory chaperones discussed above, few chaperone proteins have been identified thus far that are specific to neurons. The lack of neural-specific chaperones is somewhat surprising, considering a presumably intense requirement for chaperone action within the synaptic cleft. Recently, two neural- and endocrine-specific secretory proteins, proSAAS and 7B2, were shown to exhibit distinct anti-aggregant chaperone activities. The $7 \mathrm{~B} 2$ protein, originally identified as a neuroendocrine marker protein (Iguchi et al., 1984), exerts a potent anti-aggregant effect on the neuropeptide-synthesizing enzyme precursor, prohormone convertase 2 (proPC2); indeed, in the absence of 7B2, proPC2 undergoes inactivating aggregation (Lee and Lindberg, 2008). The anti-aggregant action of 7B2 on recombinant IGF1 produced in yeast had indeed been noted over a decade previously (Chaudhuri et al., 1995). ProSAAS was initially discovered through a peptidomics screen of abundant brain neuropeptides (Fricker et al., 2000); like 7B2, proSAAS is widely distributed within neuronal and endocrine tissues (Lanoue and Day, 2001; Feng et al., 2002). Whereas 7B2 is expressed both in vertebrates and invertebrates (for review, see Mbikay et al., 2001), proSAAS is found only in vertebrates, and residue conservation in lower vertebrates occurs only within a central core domain (Kudo et al., 2009). In agreement, mouse proSAAS undergoes limited processing at the amino and carboxy termini to several potentially bioactive peptides, but an $\sim 100$-residue core of proSAAS remains intact (Sayah et al., 2001; Mzhavia et al., 2002). No significant homology with other proteins, including known chaperones, is present within this core domain, nor are $7 \mathrm{~B} 2$ or proSAAS homologous 
with each other, despite certain structural similarities. Recombinant 7B2, an intrinsically disordered protein, spontaneously oligomerizes (Dasgupta et al., 2012) and is more soluble in the cold than at room temperature, a peculiar property reminiscent of certain small Hsps (for review, see Hilton et al., 2013). Little is known as to the tertiary or quaternary structure of proSAAS, largely due to the insolubility of the recombinant protein.

Both recombinant 7B2 as well as recombinant proSAAS dosedependently block the aggregation of $A \beta$ into thioflavin-T binding fibrils as well as $\mathrm{A} \beta$-induced cytotoxicity (Helwig et al., 2013; Hoshino et al., 2014). Inhibition is ATP-independent and substoichiometric (Helwig et al., 2013; Hoshino et al., 2014). For both proteins, anti-aggregation action appears to approximately localize to the core sequence discussed above (Helwig et al., 2013; Hoshino et al., 2014; T. Jarvela and I. Lindberg, unpublished results). Recent work shows that proSAAS also functions as a potent anti-aggregant for $\alpha$-syn (T. Jarvela and I. Lindberg, unpublished results). Indeed, proSAAS immunoreactivity colocalizes with Lewy bodies in nigral slices from a Parkinson's patient (M. Helwig and I. Lindberg, unpublished results), supporting results of earlier studies demonstrating that proSAAS colocalizes with inclusion bodies in neurodegenerative disease (Kikuchi et al., 2003; Wada et al., 2004).

Additional support for the idea that proSAAS could be involved in neurodegenerative processes is supplied by the fact that five independent proteomics studies have identified proSAAS as a potential CSF biomarker in various neurodegenerative diseases (Davidsson et al., 2002; Abdi et al., 2006; Finehout et al., 2007; Jahn et al., 2011; Choi et al., 2013), with four proteomics studies finding alterations in 7B2 levels (Pasinetti et al., 2006; Finehout et al., 2007; Bayés and Grant, 2009; Jahn et al., 2011). Collectively, these studies support the idea that neuronal $7 \mathrm{~B} 2$ and proSAAS not only represent potential therapeutic targets for controlling protein aggregation in neurodegenerative disease, but may also constitute useful biomarkers.

\section{Controlling tau aggregation and toxicity with $\mathrm{Hsp} 90$ chaperone complexes}

The microtubule-associated protein tau accumulates in a number of neurodegenerative diseases termed tauopathies, leading to formation of neurofibrillary tangles, neuronal loss, and cognitive deficits. This pathogenic cascade can be caused by mutations in the MAPT gene itself that codes for tau protein and by post-translational modifications, including phosphorylation and acetylation (Goedert et al., 1988; Hutton et al., 1998; Spillantini et al., 1998; Zhou et al., 2000; von Bergen et al., 2001; Mueller et al., 2006; Ma et al., 2012a, b). Interestingly, another post-translational modification to tau, ubiquitination, has been shown to be required for tau $\beta$-sheet assembly in vivo. However, when ubiquitination is blocked, soluble tau intermediates arise in the brain that are highly toxic (Dickey et al., 2006). The idea that soluble tau intermediates represent the major toxic species in the brain has gained recent support from key studies that have emerged over the past decade (Santacruz et al., 2005; Oddo et al., 2006; O'Leary et al., 2010; Thuringer et al., 2013). More recently, using tools that have been developed to specifically investigate oligomeric tau species, it has been proven that oligomeric tau is responsible for much of the neurotoxicity due to tau accumulation (Hall and Patuto, 2012; Blair et al., 2013). It is clear that understanding the processes governing tau oligomerization and aggregation is critical not only for controlling tau pathogenesis but also for developing tau-based therapeutics.

Although recent evidence suggests that intermediate oligomers of tau are more neurotoxic in tauopathies than densely packed $\beta$-sheet fibrils, this has remained unproven because relevant mechanisms to trap distinct assemblies of tau aggregates have been lacking. The Hsp90/cochaperone machinery can be used to control tau structure and assembly to investigate how tau aggregate structure relates to its toxicity. Tau physically interacts with Hsp90, and indeed provided the first 3D structure of a client complexed with Hsp90 (Karagöz et al., 2014). Whereas Hsp90 levels are largely static in the aging brain, a group of cochaperones that can interface with tau through Hsp90 is much more dynamic; some rise and others fall during a lifetime. Interestingly, Hsp90 and a recently identified cochaperone, the cis-/trans peptidyl-prolyl isomerase (PPIase) FK506 binding protein 51 (FKBP51), coordinate to provoke tau pathogenesis by reducing tau $\beta$-sheet amyloidosis (Blair et al., 2013). This corresponds with increased oligomerization and neurotoxicity in tau transgenic mice. Thus, the Hsp90 complex may control whether tau aggregates into toxic or benign species, depending on the associated cochaperones.

Just as FKBP51 levels increase in the aging brain, so do the levels of a second Hsp90-associated cochaperone and to an even greater extent than FKBP51 (C. A. Dickey et al., unpublished results). Like FKBP51, this second cochaperone protein reduces tau aggregation and produces amorphous intermediates. Two other cochaperones enhance the $\beta$-sheet propensity of tau (C. A. Dickey et al., unpublished results). These new proteostatic tools have permitted the interrogation of the role of tau aggregation in neurotoxicity. These studies suggest that it may be possible to identify ways to regulate tau aggregation using the dynamic Hsp90 complex, which then guides the identification of toxic tau intermediate structures. Preliminary results indicate that distinct $\mathrm{Hsp} 90 / \mathrm{co}$ chaperone complexes can differentially triage aberrant tau, illuminating heteromeric complexes that could be targeted for therapeutic development. Increasing evidence indicates that the triage of normal tau within the cell is largely dependent on the associated chaperone complement, and that these chaperone complexes govern tau triage to microtubules, lysosomes, and even exosomes. Insight into the control of cellular triage decisions is critical for our understanding of tau biology and its role in neurodegenerative disease.

\section{Hsp90 inhibitors as potential therapeutics for Parkinson's disease and related synucleinopathies}

Hsps colocalize with misfolded and aggregated proteins in multiple neurodegenerative disorders, including Parkinson's disease (PD) (Jones et al., 2014). One of the most widely studied molecular chaperone Hsps with respect to neurodegenerative disorders is Hsp70, which can direct misfolded and potentially toxic proteins for degradation via the proteasome or autophagy-lysosomal pathways (Petrucelli et al., 2004; Kon and Cuervo, 2010; Ebrahimi-Fakhari et al., 2011). Induction of Hsp70 is protective in models of Huntington's disease, spinocerebellar ataxias, and tauopathy disorders (i.e., Alzheimer's disease) (Fujikake et al., 2008; Deture et al., 2010). Several groups have demonstrated that Hsp70 upregulation enhances degradation of misfolded $\alpha$-syn, reduces $\alpha$-syn oligomer formation, and reduces toxicity induced by $\alpha$-syn overexpression (Auluck et al., 2002; McLean et al., 2002, 2004; Klucken et al., 2006). Indeed, crossing mice overexpressing Hsp70 with $\alpha$-syn transgenic mice reduces insoluble, high molecular weight $\alpha$-syn species, which are also found in the brains of patients with Lewy body-associated dementia, but not healthy controls (Klucken et al., 2006). Moreover, direct pharmacological upregulation of Hsp70 with various Hsp90 inhibitors decreases $\alpha$-syn-induced cytotoxicity and aggregation (McLean et al., 2004; Putcha et al., 2010). Thus, targeting molecular chaperones, such as Hsp70 or Hsp90, is therapeutically relevant not only for PD, but also for related neurodegenerative disorders. 
Because HSPs have emerged as potentially therapeutic modifiers of cytotoxicity in PD, mounting data suggest that upregulating Hsp70, either directly by overexpression or indirectly via inhibition of Hsp90, could be a favorable therapeutic approach. Indeed, treatment with novel, brain-permeable Hsp90 inhibitors increases Hsp70 levels and reduces $\alpha$-syn-induced aggregation and toxicity in cell models (Putcha et al., 2010). In rats, the same compounds dramatically induce Hsp70 expression in rat brain, prevent $\alpha$-syn oligomer formation in vivo, and restore lost dopamine levels in the striatum (McFarland et al., 2014). Unfortunately, a major limitation of Hsp90 inhibitor therapy is the associated widespread toxicity, which has been reported for almost all Hsp90 inhibitors tested in vivo to date.

Because Hsp90 inhibitor therapy may prove an unreasonable therapeutic approach, other related pathways have been investigated. In support of a therapeutic role for Hsp70 upregulation for $\mathrm{PD}$, the cochaperone carboxyl terminus of Hsp70-interacting protein (CHIP) colocalizes with $\alpha$-syn and Hsp70 in LBs in human brain (Shin et al., 2005) and mediates ubiquitination of $\alpha$-syn (Kalia et al., 2011). CHIP can mediate $\alpha$-syn degradation via two discrete mechanisms: the proteasomal degradation pathway and the lysosomal degradation pathway. CHIP overexpression inhibits $\alpha$-syn inclusion formation and also reduces $\alpha$-syn protein levels in cell models (Shin et al., 2005). Furthermore, using a novel bimolecular complementation assay, CHIP was shown to selectively target toxic $\alpha$-syn oligomers for degradation (Tetzlaff et al., 2008). As such, modulating CHIP levels may represent an additional therapeutic strategy for PD.

In addition to inducing a heat shock response and upregulating Hsp70, inhibition of Hsp90 may also prevent the release of extracellular $\alpha$-syn and thus prevent or slow the propagation of $\alpha$-syn pathology and disease progression. Extracellular $\alpha$-syn is resecreted out of neurons by a regulator of the recycling endosome Rab11a (Liu et al., 2009), and Hsp90 interacts with Rabl1a during this process. Hsp90 inhibition prevents the resecretion of extracellular $\alpha$-syn and attenuates the associated toxicity. The rapidly evolving field of PD propagation has resulted in a plethora of studies on extracellular $\alpha$-syn. Of interest, upregulation of Hsp70 reduces extracellular oligomers by a striking $84 \%$ and rescues associated toxicity in cell culture models (Danzer et al., 2011).

In sum, targeting the cytoplasmic chaperone Hsp90, and thereby augmenting the cellular response to stressors, may represent a reasonable therapeutic approach for neurodegenerative diseases but still requires further investigation and drug discovery efforts.

In conclusion, it is now clear that disease- and aging-associated defects in neuronal proteostasis underlie many of the cellular manifestations of neurodegenerative disease, and the various roles of chaperone proteins in controlling the formation, disposition, and cytotoxicity of aberrant protein aggregates are accordingly receiving increasing attention. These brief summaries of current work present diverse approaches to the study of chaperone proteins in neurodegeneration. The different cellular locations of chaperone action provide a variety of possibilities for chaperone use in therapeutic intervention, from controlling the initial aggregative events in the ER, to blocking the assembly of cytotoxic aggregates, to reversing the formation of extracellular toxic oligomers.

\section{References}

Abdi F, Quinn JF, Jankovic J, McIntosh M, Leverenz JB, Peskind E, Nixon R, Nutt J, Chung K, Zabetian C, Samii A, Lin M, Hattan S, Pan C, Wang Y, Jin J, Zhu D, Li GJ, Liu Y, Waichunas D, et al. (2006) Detection of biomarkers with a multiplex quantitative proteomic platform in cerebrospinal fluid of patients with neurodegenerative disorders. J Alzheimers Dis 9:293-348. Medline

Alexopoulos JA, Guarné A, Ortega J (2012) ClpP: a structurally dynamic protease regulated by $\mathrm{AAA}^{+}$proteins. J Struct Biol 179:202-210. CrossRef Medline

Auluck PK, Chan HY, Trojanowski JQ, Lee VM, Bonini NM (2002) Chaperone suppression of alpha-synuclein toxicity in a Drosophila model for Parkinson's disease. Science 295:865-868. CrossRef Medline

Bayés A, Grant SG (2009) Neuroproteomics: understanding the molecular organization and complexity of the brain. Nat Rev Neurosci 10:635-646. CrossRef Medline

Binger KJ, Ecroyd H, Yang S, Carver JA, Howlett GJ, Griffin MD (2013) Avoiding the oligomeric state: $\alpha \mathrm{B}$-crystallin inhibits fragmentation and induces dissociation of apolipoprotein C-II amyloid fibrils. FASEB J 27: 1214-1222. CrossRef Medline

Blair LJ, Nordhues BA, Hill SE, Scaglione KM, O’Leary JC 3rd, Fontaine SN, Breydo L, Zhang B, Li P, Wang L, Cotman C, Paulson HL, Muschol M, Uversky VN, Klengel T, Binder EB, Kayed R, Golde TE, Berchtold N, Dickey CA (2013) Accelerated neurodegeneration through chaperonemediated oligomerization of tau. J Clin Invest 123:4158-4169. CrossRef Medline

Blancas-Mejía LM, Ramirez-Alvarado M (2013) Systemic amyloidoses. Annu Rev Biochem 82:745-774. CrossRef Medline

Buxbaum JN, Ye Z, Reixach N, Friske L, Levy C, Das P, Golde T, Masliah E, Roberts AR, Bartfai T (2008) Transthyretin protects Alzheimer's mice from the behavioral and biochemical effects of Abeta toxicity. Proc Natl Acad Sci U S A 105:2681-2686. CrossRef Medline

Carman A, Kishinevsky S, Koren J, Lou W, Chiosis G (2013) Chaperonedependent neurodegeneration: a molecular perspective on therapeutic intervention. J Alzheimers Dis Parkinsonism 2013[Suppl 10]:pii007.

Cascella R, Conti S, Mannini B, Li X, Buxbaum JN, Tiribilli B, Chiti F, Cecchi C (2013) Transthyretin suppresses the toxicity of oligomers formed by misfolded proteins in vitro. Biochim Biophys Acta 1832:2302-2314. CrossRef Medline

Cashikar AG, Duennwald M, Lindquist SL (2005) A chaperone pathway in protein disaggregation. Hsp26 alters the nature of protein aggregates to facilitate reactivation by Hsp104. J Biol Chem 280:23869-23875. CrossRef Medline

Chaudhuri B, Stephan C, Huijbregts RP, Martens GJ (1995) The neuroendocrine protein $7 \mathrm{~B} 2$ acts as a molecular chaperone in the in vitro folding of human insulin-like growth factor-1 secreted from yeast. Biochem Biophys Res Commun 211:417-425. CrossRef Medline

Choi SH, Leight SN, Lee VM, Li T, Wong PC, Johnson JA, Saraiva MJ, Sisodia SS (2007) Accelerated Abeta deposition in APPswe/PS1 $\delta E 9$ mice with hemizygous deletions of TTR (transthyretin). J Neurosci 27:7006-7010. CrossRef Medline

Choi YS, Hou S, Choe LH, Lee KH (2013) Targeted human cerebrospinal fluid proteomics for the validation of multiple Alzheimer's disease biomarker candidates. J Chromatogr B Analyt Technol Biomed Life Sci 930: 129-135. CrossRef Medline

Cooley CB, Ryno LM, Plate L, Morgan GJ, Hulleman JD, Kelly JW, Wiseman RL (2014) Unfolded protein response activation reduces secretion and extracellular aggregation of amyloidogenic immunoglobulin light chain. Proc Natl Acad Sci U S A 111:13046-13051. CrossRef Medline

Couthouis J, Hart MP, Erion R, King OD, Diaz Z, Nakaya T, Ibrahim F, Kim HJ, Mojsilovic-Petrovic J, Panossian S, Kim CE, Frackelton EC, Solski JA, Williams KL, Clay-Falcone D, Elman L, McCluskey L, Greene R, Hakonarson H, Kalb RG, et al. (2012) Evaluating the role of the FUS/TLSrelated gene EWSR1 in amyotrophic lateral sclerosis. Hum Mol Genet 21:2899-2911. CrossRef Medline

Cushman M, Johnson BS, King OD, Gitler AD, Shorter J (2010) Prion-like disorders: blurring the divide between transmissibility and infectivity. J Cell Sci 123:1191-1201. CrossRef Medline

Danzer KM, Ruf WP, Putcha P, Joyner D, Hashimoto T, Glabe C, Hyman BT, McLean PJ (2011) Heat-shock protein 70 modulates toxic extracellular $\alpha$-synuclein oligomers and rescues trans-synaptic toxicity. FASEB J 25 : 326-336. CrossRef Medline

Dasgupta I, Sanglas L, Enghild JJ, Lindberg I (2012) The neuroendocrine protein $7 \mathrm{~B} 2$ is intrinsically disordered. Biochemistry 51:7456-7464. CrossRef Medline

Davidsson P, Sjögren M, Andreasen N, Lindbjer M, Nilsson CL, WestmanBrinkmalm A, Blennow K (2002) Studies of the pathophysiological mechanisms in frontotemporal dementia by proteome analysis of CSF proteins. Brain Res Mol Brain Res 109:128-133. CrossRef Medline

DeSantis ME, Leung EH, Sweeny EA, Jackrel ME, Cushman-Nick M, 
Neuhaus-Follini A, Vashist S, Sochor MA, Knight MN, Shorter J (2012) Operational plasticity enables hsp104 to disaggregate diverse amyloid and nonamyloid clients. Cell 151:778-793. CrossRef Medline

Deture M, Hicks C, Petrucelli L (2010) Targeting heat shock proteins in tauopathies. Curr Alzheimer Res 7:677-684. CrossRef Medline

Dickey CA, Yue M, Lin WL, Dickson DW, Dunmore JH, Lee WC, Zehr C, West G, Cao S, Clark AM, Caldwell GA, Caldwell KA, Eckman C, Patterson C, Hutton M, Petrucelli L (2006) Deletion of the ubiquitin ligase CHIP leads to the accumulation, but not the aggregation, of both endogenous phospho- and caspase-3-cleaved tau species. J Neurosci 26:69856996. CrossRef Medline

Doyle SM, Genest O, Wickner S (2013) Protein rescue from aggregates by powerful molecular chaperone machines. Nat Rev Mol Cell Biol 14:617629. CrossRef Medline

Ebrahimi-Fakhari D, Cantuti-Castelvetri I, Fan Z, Rockenstein E, Masliah E, Hyman BT, McLean PJ, Unni VK (2011) Distinct roles in vivo for the ubiquitin-proteasome system and the autophagy-lysosomal pathway in the degradation of $\alpha$-synuclein. J Neurosci 31:14508-14520. CrossRef Medline

Eisenberg D, Jucker M (2012) The amyloid state of proteins in human diseases. Cell 148:1188-1203. CrossRef Medline

Feng Y, Reznik SE, Fricker LD (2002) ProSAAS and prohormone convertase 1 are broadly expressed during mouse development. Brain Res Gene Expr Patterns 1:135-140. CrossRef Medline

Finehout EJ, Franck Z, Choe LH, Relkin N, Lee KH (2007) Cerebrospinal fluid proteomic biomarkers for Alzheimer's disease. Ann Neurol 61: 120-129. CrossRef Medline

Fricker LD, McKinzie AA, Sun J, Curran E, Qian Y, Yan L, Patterson SD, Courchesne PL, Richards B, Levin N, Mzhavia N, Devi LA, Douglass J (2000) Identification and characterization of proSAAS, a granin-like neuroendocrine peptide precursor that inhibits prohormone processing. J Neurosci 20:639-648. Medline

Fujikake N, Nagai Y, Popiel HA, Okamoto Y, Yamaguchi M, Toda T (2008) Heat shock transcription factor 1-activating compounds suppress polyglutamineinduced neurodegeneration through induction of multiple molecular chaperones. J Biol Chem 283:26188-26197. CrossRef Medline

Genereux JC, Qu S, Zhou M, Ryno LM, Wang S, Shoulders MD, Kaufman RJ, Lasmézas CI, Kelly JW, Wiseman RL (2015) Unfolded protein responseinduced ERdj3 secretion links ER stress to extracellular proteostasis. EMBO J 34:4-19. CrossRef Medline

Glover JR, Lindquist S (1998) Hsp104, Hsp70, and Hsp40: a novel chaperone system that rescues previously aggregated proteins. Cell 94:73-82. CrossRef Medline

Goedert M, Wischik CM, Crowther RA, Walker JE, Klug A (1988) Cloning and sequencing of the cDNA encoding a core protein of the paired helical filament of Alzheimer disease: identification as the microtubuleassociated protein tau. Proc Natl Acad Sci U S A 85:4051-4055. CrossRef Medline

Hall GF, Patuto BA (2012) Is tau ready for admission to the prion club? Prion 6:223-233. CrossRef Medline

Hartl FU, Bracher A, Hayer-Hartl M (2011) Molecular chaperones in protein folding and proteostasis. Nature 475:324-332. CrossRef Medline

Helwig M, Hoshino A, Berridge C, Lee SN, Lorenzen N, Otzen DE, Eriksen JL, Lindberg I (2013) The neuroendocrine protein 7B2 suppresses the aggregation of neurodegenerative disease-related proteins. J Biol Chem 288: 1114-1124. CrossRef Medline

Hetz C, Mollereau B (2014) Disturbance of endoplasmic reticulum proteostasis in neurodegenerative diseases. Nat Rev Neurosci 15:233-249. CrossRef Medline

Hilton GR, Lioe H, Stengel F, Baldwin AJ, Benesch JL (2013) Small heatshock proteins: paramedics of the cell. Top Curr Chem 328:69-98. CrossRef Medline

Hodson S, Marshall JJ, Burston SG (2012) Mapping the road to recovery: the ClpB/ Hsp104 molecular chaperone. J Struct Biol 179:161-171. CrossRef Medline

Hoshino A, Helwig M, Rezaei S, Berridge C, Eriksen JL, Lindberg I (2014) A novel function for proSAAS as an amyloid anti-aggregant in Alzheimer's disease. J Neurochem 128:419-430. CrossRef Medline

Hutton M, Lendon CL, Rizzu P, Baker M, Froelich S, Houlden H, PickeringBrown S, Chakraverty S, Isaacs A, Grover A, Hackett J, Adamson J, Lincoln S, Dickson D, Davies P, Petersen RC, Stevens M, de GraaffE, Wauters E, van Baren J, et al. (1998) Association of missense and 5'-splice-site mutations in tau with the inherited dementia FTDP-17. Nature 393:702705. CrossRef Medline

Iguchi H, Chan JS, Seidah NG, Chrétien M (1984) Tissue distribution and molecular forms of a novel pituitary protein in the rat. Neuroendocrinology 39:453-458. CrossRef Medline

Jackrel ME, Shorter J (2014) Potentiated Hsp104 variants suppress toxicity of diverse neurodegenerative disease-linked proteins. Dis Model Mech 7:1175-1184. CrossRef Medline

Jackrel ME, Shorter J (2015) Engineering enhanced protein disaggregases for neurodegenerative disease. Prion 9:90-109. CrossRef Medline

Jackrel ME, DeSantis ME, Martinez BA, Castellano LM, Stewart RM, Caldwell KA, Caldwell GA, Shorter J (2014) Potentiated Hsp104 variants antagonize diverse proteotoxic misfolding events. Cell 156:170-182. CrossRef Medline

Jahn H, Wittke S, Zürbig P, Raedler TJ, Arlt S, Kellmann M, Mullen W, Eichenlaub M, Mischak H, Wiedemann K (2011) Peptide fingerprinting of Alzheimer's disease in cerebrospinal fluid: identification and prospective evaluation of new synaptic biomarkers. PLoS One 6:e26540. CrossRef Medline

Jones DR, Moussaud S, McLean P (2014) Targeting heat shock proteins to modulate alpha-synuclein toxicity. Ther Adv Neurol Disord 7:33-51. CrossRef Medline

Kalia LV, Kalia SK, Chau H, Lozano AM, Hyman BT, McLean PJ (2011) Ubiquitinylation of $\alpha$-synuclein by carboxyl terminus Hsp70-interacting protein (CHIP) is regulated by $\mathrm{Bcl}-2$-associated athanogene 5 (BAG5). PLoS One 6:e14695. CrossRef Medline

Karagöz GE, Duarte AM, Akoury E, Ippel H, Biernat J, Morán Luengo T, Radli M, Didenko T, Nordhues BA, Veprintsev DB, Dickey CA, Mandelkow E, Zweckstetter M, Boelens R, Madl T, Rüdiger SG (2014) Hsp90-Tau complex reveals molecular basis for specificity in chaperone action. Cell 156:963-974. CrossRef Medline

Kikuchi K, Arawaka S, Koyama S, Kimura H, Ren CH, Wada M, Kawanami T, Kurita K, Daimon M, Kawakatsu S, Kadoya T, Goto K, Kato T (2003) An $\mathrm{N}$-terminal fragment of ProSAAS (a granin-like neuroendocrine peptide precursor) is associated with tau inclusions in Pick's disease. Biochem Biophys Res Commun 308:646-654. CrossRef Medline

Kim YE, Hipp MS, Bracher A, Hayer-Hartl M, Hartl FU (2013) Molecular chaperone functions in protein folding and proteostasis. Annu Rev Biochem 82:323-355. CrossRef Medline

King OD, Gitler AD, Shorter J (2012) The tip of the iceberg: RNA-binding proteins with prion-like domains in neurodegenerative disease. Brain Res 1462:61-80. CrossRef Medline

Klucken J, Ingelsson M, Shin Y, Irizarry MC, Hedley-Whyte ET, Frosch M, Growdon J, McLean P, Hyman BT (2006) Clinical and biochemical correlates of insoluble alpha-synuclein in dementia with Lewy bodies. Acta Neuropathol 111:101-108. CrossRef Medline

Knowles TP, Vendruscolo M, Dobson CM (2014) The amyloid state and its association with protein misfolding diseases. Nat Rev Mol Cell Biol 15: 384-396. CrossRef Medline

Kon M, Cuervo AM (2010) Chaperone-mediated autophagy in health and disease. FEBS Lett 584:1399-1404. CrossRef Medline

Kudo H, Liu J, Jansen EJ, Ozawa A, Panula P, Martens GJ, Lindberg I (2009) Identification of proSAAS homologs in lower vertebrates: conservation of hydrophobic helices and convertase-inhibiting sequences. Endocrinology 150:1393-1399. CrossRef Medline

Lanoue E, Day R (2001) Coexpression of proprotein convertase SPC3 and the neuroendocrine precursor proSAAS. Endocrinology 142:4141-4149. CrossRef Medline

Lee SN, Lindberg I (2008) 7B2 prevents unfolding and aggregation of prohormone convertase 2. Endocrinology 149:4116-4127. CrossRef Medline

Li T, Lucius AL (2013) Examination of the polypeptide substrate specificity for Escherichia coli ClpA. Biochemistry 52:4941-4954. CrossRef Medline

Li X, Masliah E, Reixach N, Buxbaum JN (2011) Neuronal production of transthyretin in human and murine Alzheimer's disease: is it protective? J Neurosci 31:12483-12490. CrossRef Medline

Li X, Zhang X, Ladiwala AR, Du D, Yadav JK, Tessier PM, Wright PE, Kelly JW, Buxbaum JN (2013) Mechanisms of transthyretin inhibition of $\beta$-amyloid aggregation in vitro. J Neurosci 33:19423-19433. CrossRef Medline

Ling SC, Polymenidou M, Cleveland DW (2013) Converging mechanisms in ALS and FTD: disrupted RNA and protein homeostasis. Neuron 79: 416-438. CrossRef Medline 
Liu J, Zhang JP, Shi M, Quinn T, Bradner J, Beyer R, Chen S, Zhang J (2009) Rab1la and HSP90 regulate recycling of extracellular alpha-synuclein. J Neurosci 29:1480-1485. CrossRef Medline

Lo Bianco C, Shorter J, Régulier E, Lashuel H, Iwatsubo T, Lindquist S, Aebischer P (2008) Hsp104 antagonizes alpha-synuclein aggregation and reduces dopaminergic degeneration in a rat model of Parkinson disease. J Clin Invest 118:3087-3097. CrossRef Medline

Ma SL, Pastorino L, Zhou XZ, Lu KP (2012a) Prolyl isomerase Pinl promotes amyloid precursor protein (APP) turnover by inhibiting glycogen synthase kinase-3 $\beta$ (GSK3 $\beta$ ) activity: novel mechanism for Pin1 to protect against Alzheimer disease. J Biol Chem 287:6969-6973. CrossRef Medline

Ma SL, Tang NL, Tam CW, Lui VW, Lam LC, Chiu HF, Driver JA, Pastorino L, Lu KP (2012b) A PIN1 polymorphism that prevents its suppression by AP4 associates with delayed onset of Alzheimer's disease. Neurobiol Aging 33:804-813. CrossRef Medline

Mannini B, Mulvihill E, Sgromo C, Cascella R, Khodarahmi R, Ramazzotti M, Dobson CM, Cecchi C, Chiti F (2014) Toxicity of protein oligomers is rationalized by a function combining size and surface hydrophobicity. ACS Chem Biol 9:2309-2317. CrossRef Medline

Mbikay M, Seidah NG, Chrétien M (2001) Neuroendocrine secretory protein 7B2: structure, expression and functions. Biochem J 357:329-342. CrossRef Medline

McFarland NR, Dimant H, Kibuuka L, Ebrahimi-Fakhari D, Desjardins CA, Danzer KM, Danzer M, Fan Z, Schwarzschild MA, Hirst W, McLean PJ (2014) Chronic treatment with novel small molecule Hsp90 inhibitors rescues striatal dopamine levels but not $\alpha$-synuclein-induced neuronal cell loss. PLoS One 9:e86048. CrossRef Medline

McLean PJ, Kawamata H, Shariff S, Hewett J, Sharma N, Ueda K, Breakefield XO, Hyman BT (2002) TorsinA and heat shock proteins act as molecular chaperones: suppression of alpha-synuclein aggregation. J Neurochem 83:846-854. CrossRef Medline

McLean PJ, Klucken J, Shin Y, Hyman BT (2004) Geldanamycin induces Hsp70 and prevents alpha-synuclein aggregation and toxicity in vitro. Biochem Biophys Res Commun 321:665-669. CrossRef Medline

Mueller JW, Kessler D, Neumann D, Stratmann T, Papatheodorou P, Hartmann-Fatu C, Bayer P (2006) Characterization of novel elongated Parvulin isoforms that are ubiquitously expressed in human tissues and originate from alternative transcription initiation. BMC Mol Biol 7:9. CrossRef Medline

Mzhavia N, Qian Y, Feng Y, Che FY, Devi LA, Fricker LD (2002) Processing of proSAAS in neuroendocrine cell lines. Biochem J 361:67-76. CrossRef Medline

Oddo S, Vasilevko V, Caccamo A, Kitazawa M, Cribbs DH, LaFerla FM (2006) Reduction of soluble Abeta and tau, but not soluble Abeta alone, ameliorates cognitive decline in transgenic mice with plaques and tangles. J Biol Chem 281:39413-39423. CrossRef Medline

Ojha J, Masilamoni G, Dunlap D, Udoff RA, Cashikar AG (2011) Sequestration of toxic oligomers by HspB1 as a cytoprotective mechanism. Mol Cell Biol 31:3146-3157. CrossRef Medline

O’Leary JC 3rd, Li Q, Marinec P, Blair LJ, Congdon EE, Johnson AG, Jinwal UK, Koren J 3rd, Jones JR, Kraft C, Peters M, Abisambra JF, Duff KE, Weeber EJ, Gestwicki JE, Dickey CA (2010) Phenothiazine-mediated rescue of cognition in tau transgenic mice requires neuroprotection and reduced soluble tau burden. Mol Neurodegener 5:45. CrossRef Medline

Pasinetti GM, Ungar LH, Lange DJ, Yemul S, Deng H, Yuan X, Brown RH, Cudkowicz ME, Newhall K, Peskind E, Marcus S, Ho L (2006) Identification of potential CSF biomarkers in ALS. Neurology 66:1218-1222. CrossRef Medline

Petrucelli L, Dickson D, Kehoe K, Taylor J, Snyder H, Grover A, De Lucia M, McGowan E, Lewis J, Prihar G, Kim J, Dillmann WH, Browne SE, Hall A, Voellmy R, Tsuboi Y, Dawson TM, Wolozin B, Hardy J, Hutton M (2004) CHIP and Hsp70 regulate tau ubiquitination, degradation and aggregation. Hum Mol Genet 13:703-714. CrossRef Medline

Pickart CM, Cohen RE (2004) Proteasomes and their kin: proteases in the machine age. Nat RevMol Cell Biol 5:177-187. CrossRef Medline

Putcha P, Danzer KM, Kranich LR, Scott A, Silinski M, Mabbett S, Hicks CD, Veal JM, Steed PM, Hyman BT, McLean PJ (2010) Brain-permeable small-molecule inhibitors of Hsp90 prevent alpha-synuclein oligomer formation and rescue alpha-synuclein-induced toxicity. J Pharmacol Exp Ther 332:849-857. CrossRef Medline

Ryno LM, Wiseman RL, Kelly JW (2013) Targeting unfolded protein re- sponse signaling pathways to ameliorate protein misfolding diseases. Curr Opin Chem Biol 17:346-352. CrossRef Medline

Santacruz K, Lewis J, Spires T, Paulson J, Kotilinek L, Ingelsson M, Guimaraes A, DeTure M, Ramsden M, McGowan E, Forster C, Yue M, Orne J, Janus C, Mariash A, Kuskowski M, Hyman B, Hutton M, Ashe KH (2005) Tau suppression in a neurodegenerative mouse model improves memory function. Science 309:476-481. CrossRef Medline

Sayah M, Fortenberry Y, Cameron A, Lindberg I (2001) Tissue distribution and processing of proSAAS by proprotein convertases. J Neurochem 76 : 1833-1841. CrossRef Medline

Schwarzman AL, Gregori L, Vitek MP, Lyubski S, Strittmatter WJ, Enghilde JJ, Bhasin R, Silverman J, Weisgraber KH, Coyle PK (1994) Transthyretin sequesters amyloid beta protein and prevents amyloid formation. Proc Natl Acad Sci U S A 91:8368-8372. CrossRef Medline

Shin Y, Klucken J, Patterson C, Hyman BT, McLean PJ (2005) The cochaperone carboxyl terminus of Hsp70-interacting protein (CHIP) mediates alpha-synuclein degradation decisions between proteasomal and lysosomal pathways. J Biol Chem 280:23727-23734. CrossRef Medline

Shorter J (2011) The mammalian disaggregase machinery: Hsp110 synergizes with $\mathrm{Hsp} 70$ and $\mathrm{Hsp} 40$ to catalyze protein disaggregation and reactivation in a cell-free system. PLoS One 6:e26319. CrossRef Medline

Shorter J, Lindquist S (2004) Hsp104 catalyzes formation and elimination of selfreplicating Sup35 prion conformers. Science 304:1793-1797. CrossRef Medline

Shoulders MD, Ryno LM, Genereux JC, Moresco JJ, Tu PG, Wu C, Yates JR 3rd, Su AI, Kelly JW, Wiseman RL (2013) Stress-independent activation of XBP1s and/or ATF6 reveals three functionally diverse ER proteostasis environments. Cell Rep 3:1279-1292. CrossRef Medline

Spillantini MG, Murrell JR, Goedert M, Farlow MR, Klug A, Ghetti B (1998) Mutation in the tau gene in familial multiple system tauopathy with presenile dementia. Proc Natl Acad Sci U S A 95:7737-7741. CrossRef Medline

Tetzlaff JE, Putcha P, Outeiro TF, Ivanov A, Berezovska O, Hyman BT, McLean PJ (2008) CHIP targets toxic alpha-synuclein oligomers for degradation. J Biol Chem 283:17962-17968. CrossRef Medline

Thuringer D, Jego G, Wettstein G, Terrier O, Cronier L, Yousfi N, Hébrard S, Bouchot A, Hazoumé A, Joly AL, Gleave M, Rosa-Calatrava M, Solary E, Garrido C (2013) Extracellular HSP27 mediates angiogenesis through Toll-like receptor 3. FASEB J 27:4169-4183. CrossRef Medline

Torrente MP, Shorter J (2013) The metazoan protein disaggregase and amyloid depolymerase system: Hsp110, Hsp70, Hsp40, and small heat shock proteins. Prion 7:457-463. CrossRef Medline

Valastyan JS, Lindquist S (2014) Mechanisms of protein-folding diseases at a glance. Dis Model Mech 7:9-14. CrossRef Medline

von Bergen M, Barghorn S, Li L, Marx A, Biernat J, Mandelkow EM, Mandelkow E (2001) Mutations of tau protein in frontotemporal dementia promote aggregation of paired helical filaments by enhancing local betastructure. J Biol Chem 276:48165-48174. Medline

Wada M, Ren CH, Koyama S, Arawaka S, Kawakatsu S, Kimura H, Nagasawa H, Kawanami T, Kurita K, Daimon M, Hirano A, Kato T (2004) A human granin-like neuroendocrine peptide precursor (proSAAS) immunoreactivity in tau inclusions of Alzheimer's disease and parkinsonismdementia complex on Guam. Neurosci Lett 356:49-52. CrossRef Medline

Walter P, Ron D (2011) The unfolded protein response: from stress pathway to homeostatic regulation. Science 334:1081-1086. CrossRef Medline

Weibezahn J, Schlieker C, Tessarz P, Mogk A, Bukau B (2005) Novel insights into the mechanism of chaperone-assisted protein disaggregation. Biol Chem 386:739-744. CrossRef Medline

Winkler J, Tyedmers J, Bukau B, Mogk A (2012) Chaperone networks in protein disaggregation and prion propagation. J Struct Biol 179:152-160. CrossRef Medline

Witt SN (2013) Molecular chaperones, alpha-synuclein, and neurodegeneration. Mol Neurobiol 47:552-560. CrossRef Medline

Wyatt AR, Yerbury JJ, Dabbs RA, Wilson MR (2012) Roles of extracellular chaperones in amyloidosis. J Mol Biol 421:499-516. CrossRef Medline

Wyatt AR, Yerbury JJ, Ecroyd H, Wilson MR (2013) Extracellular chaperones and proteostasis. Annu Rev Biochem 82:295-322. CrossRef Medline

Zhou XZ, Kops O, Werner A, Lu PJ, Shen M, Stoller G, Küllertz G, Stark M, Fischer G, Lu KP (2000) Pin1-dependent prolyl isomerization regulates dephosphorylation of Cdc25C and tau proteins. Mol Cell 6:873-883. CrossRef Medline 